\title{
Conceptualizing a decentralized stormwater treatment system for an urbanized city with improper stormwater drainage facilities
}

\author{
A. S. Arora $\cdot$ A. S. Reddy
}

Received: 23 May 2013/Revised: 8 May 2014/ Accepted: 12 July 2014/Published online: 29 July 2014

(C) Islamic Azad University (IAU) 2014

\begin{abstract}
Urbanization involving replacement of previous areas with impervious surfaces and drainage channel modifications results in increased runoff volume leading to flooding and also in deteriorating the quality of the stormwater runoff. An effective and efficient stormwater management is needed in the urban areas for mitigating the impacts and overcoming the problems associated with the urban stormwater. An attempt has been made in the present study to investigate the relationships between stormwater quality and five different land uses for the Patiala city of Punjab State. Stormwater samples collected from these locations, between April 2010 and March 2011, were analyzed for various organic and inorganic water quality parameters and heavy metals. Inter-parameter relationships studied provided vital information in deciding upon the treatment units most likely to be suitable for that particular sub-watershed. Multiple regression modeling helped in assessment of water quality parameters and predicting the quality well before actually analyzing the parameters and thus aided in developing treatment schemes suitable for taking care of the stormwater quality even under worst set of conditions. The outcomes of the research study effectively contributed toward conceptualizing a decentralized stormwater treatment system that would be capable of coping with the stormwater runoff-associated problems faced by the city and can serve as a model for other under-
\end{abstract}

Electronic supplementary material The online version of this article (doi:10.1007/s13762-014-0655-3) contains supplementary material, which is available to authorized users.

A. S. Arora $(\bowtie) \cdot$ A. S. Reddy

School of Energy and Environment, Thapar University, Patiala 147004, Punjab, India

e-mail: enviro_amar@yahoo.com developed and developing cities having improper stormwater management facilities.

Keywords Urban stormwater quality - Sub-watershed . Multiple regression analysis - Decentralized stormwater treatment

\section{Introduction}

Stormwater has been considered as a major pollution source for many urban waters (Davis et al. 2001; Birch et al. 2006). Quantification and characterization of stormwater are important for the design of the stormwater treatment system and recharge well (Taebi and Droste 2004; Birch et al. 2005). The characterization is believed to help in deciding on the parameters for which treatment is needed and on the treatment scheme to be followed, since the pollution parameters are believed to vary with the watershed characteristics, with the intensity and depth of the storm events, and with the antecedent dry periods of the storm events (Hossain et al. 2011). Knowing this variability is important in deciding on the treatment scheme and sizing of the treatment units. Many researchers have attempted to characterize stormwaters from small urban catchments/ watersheds (Yaziz et al. 1989; Deletic 1998; Choe et al. 2002; Chang et al. 2004; Chebbo and Gromaire 2004; Gnecco et al. 2005; Goonetilleke et al. 2005; Yusop et al. 2005). But very little is known about urban stormwater characteristics in Indian context in general and Patiala city in particular.

Thus, for developing a stormwater management plan for Patiala city of Punjab, India, located within a bowl-like drainage basin with planar topography, assessment of the stormwater quality is of utmost importance and will 
significantly assist in deciding the treatment units to be included for obtaining the desired quality of stormwater.

Patiala city depends on groundwater for its water supply. Multitudes of municipal and private tube wells distributed across the city are used to extract the groundwater. The groundwater table is rapidly falling (many of the tube wells have already dried up), and salt level of the groundwater is increasing (Arora and Reddy 2013).

Avoiding discharge of polluted stormwater, preventing flooding within the city and maintaining the groundwater table should be considered as utmost important while planning stormwater management system for the city. One such management strategy could involve division of the city into finite number of urban sub-watersheds and collecting stormwater at their outlets, treating the collected stormwater and finally disposing through groundwater recharging. The treatment systems and the groundwater recharge wells used should be sited at the lowest elevation points of the sub-watersheds and should preferably be very compact and mostly underground facilities. The treatment systems should be simple, rugged (requiring no human intervention especially during the storm events) and requiring least maintenance. Further, they should remain viable and maintained ready for the effective and efficient stormwater treatment (to the desired quality) during the storm events.

To achieve this objective, stormwaters from five selected sub-watersheds of the Patiala city were sampled (over six storm events during April 2010 to March 2011) and analyzed for characterization. Results obtained were used to identify the pollution parameters that should be targeted during the treatment. Interrelationships among the pollution parameters were understood and used in making decisions on the schemes of stormwater treatment. Further, efforts have also been made to model the stormwater characteristics vis-a-vis the storm event size and the antecedent dry period. These models would be sub-watershed specific and are supposed to help in assessing the stormwater characteristics of a sub-watershed and use in the treatment system development and design. Sizing of the treatment units can be done based on the hydrological studies at the sub-watershed level and quantification of stormwater. This portion of work, however, is not included in this paper.

\section{Materials and methods}

Characterization of the urban sub-watersheds and their demarcation

Five urban sub-watersheds indicated below were identified within the Patiala city to serve as sample catchments for the study. These represent the diversity of the urban watershed characteristics and conditions across the city:

1. Sub-watershed-1 (SW-1): Model Town

2. Sub-watershed-2 (SW-2): Civil Lines

3. Sub-watershed-3 (SW-3): Manjit Nagar

4. Sub-watershed-4 (SW-4): Preet Nagar

5. Sub-watershed-5 (SW-5): Bus Stand

Figure 1 shows the demarcated sample catchments/subwatersheds.

The catchments differed in the forms of land development activities and housing density. Civil Lines subwatershed is predominantly a residential catchment. Manjit Nagar sub-watershed, located near Seona village, is a mix of rural and residential acreage. Preet Nagar sub-watershed contains mixed urban development. Model Town subwatershed is predominately commercial in character. Lastly, Bus Stand sub-watershed is a heavily travelled (heavy vehicular traffic) and polluted catchment. For each of the catchments, detailed background information on the following aspects given was collected:

- Slope and hydrological path lengths toward the point of flooding

- Demographic features of the sub-watersheds

- Sub-watershed area, shape and land-use patterns within the catchments

- Social, economic and other activities of the subwatersheds

For information on the watershed characteristics, physical survey of the catchments, interviews with local people, topographical sheets, local zoning maps and maps available on the net (Google Maps, Encarta maps) were used. Patiala municipal council and Department of Town and Country planning, Punjab, were also depended on for the information. Data on storm/rainfall events were obtained from Indian Meteorological Department.

\section{Sampling and analysis}

For each of the five sample catchments, grab samples of stormwater were collected from the stormwater accumulation ditch, immediately after the rainfall event. Information on the rainfall event, such as depth of rainfall and number of dry antecedent days, was recorded for each of the events sampled. The samples were analyzed in the Environmental Laboratories of the Thapar University for the parameters $\mathrm{pH}$, conductivity, total suspended solids (TSS), total dissolved solids (TDS), biochemical oxygen demand $\left(\mathrm{BOD}_{5}\right)$ for 5 day at $20^{\circ} \mathrm{C}$, chemical oxygen demand (COD), total kjeldahl nitrogen (TKN), total phosphorous (TP), oil and grease, total coliform count, fecal coliform count and heavy metals $(\mathrm{Zn}, \mathrm{Cd}, \mathrm{Ni}, \mathrm{Pb}, \mathrm{Fe}$ 


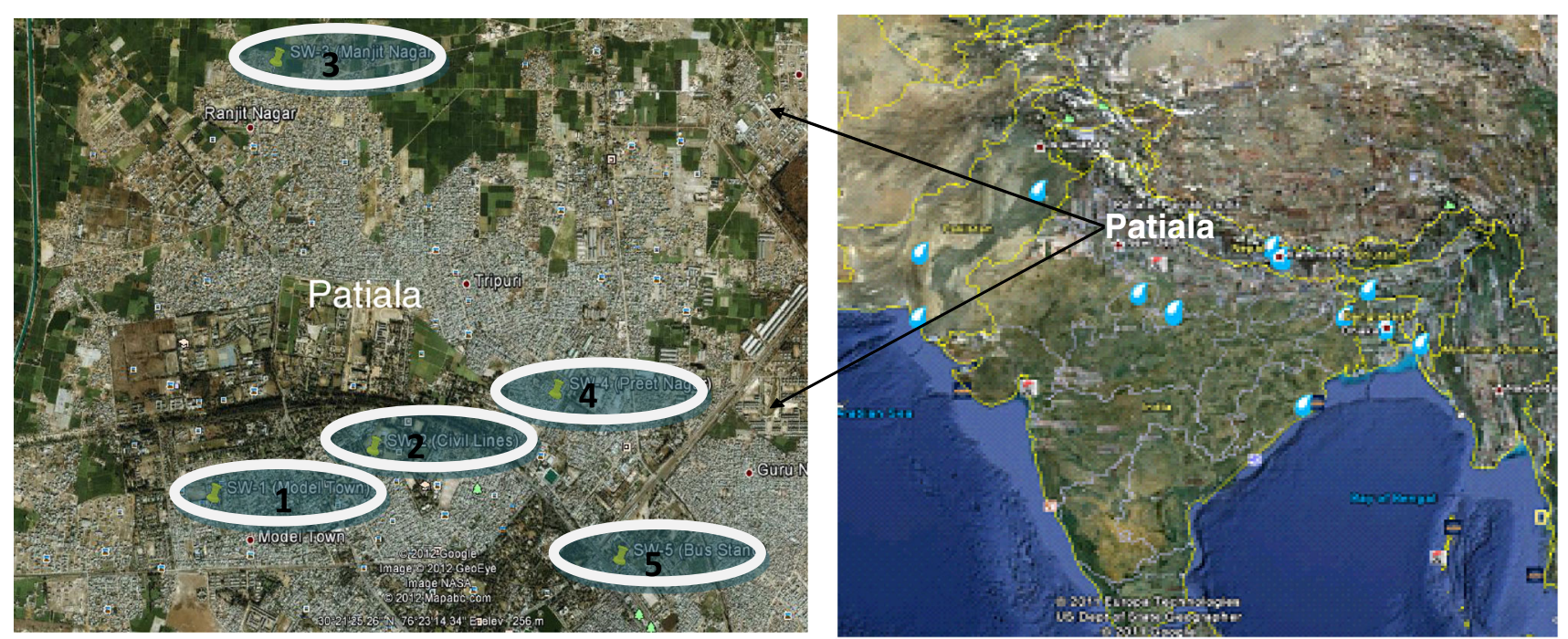

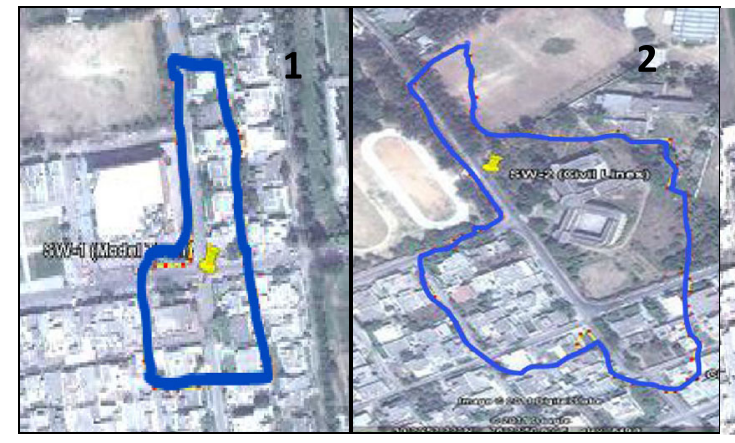

Model Town
Civil Lines

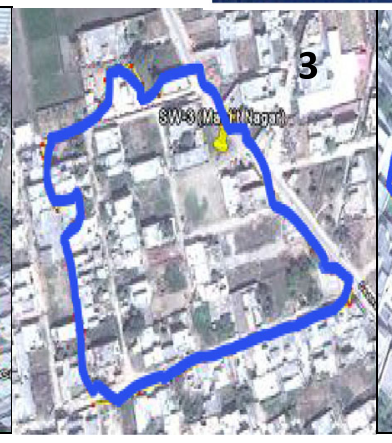

Manjit Nagar

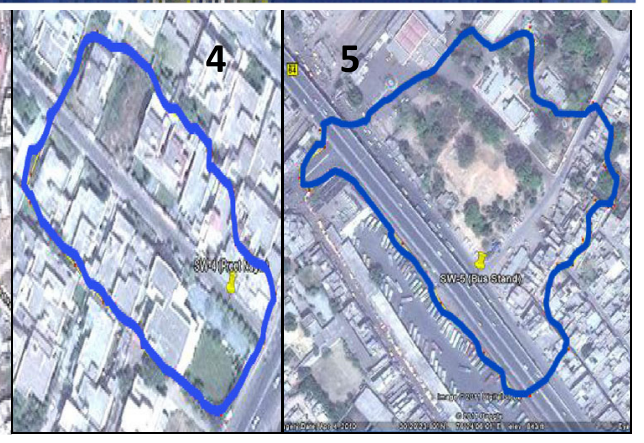

Preet Nagar

Bus Stand

Fig. 1 Map showing the locations of the sub-watersheds studied

and $\mathrm{Cu}$ ). Techniques given in the APHA 2005 were used for the analysis of the samples.

Statistical data processing

Statistical tools were used for assessing and formulating relationships between stormwater quality characteristics with the rainfall depth and antecedent dry period. The influence of antecedent dry days and volume of the rainfall was analyzed and modeled through multiple regression analysis for each of the watersheds separately. Regression models were formulated using software MiniTab version 16 , and regression equations were formulated for all the identified significant parameters.

Further, correlations among the stormwater quality parameters were established using Spearman's nonparametric rank correlation procedure. Only the relationships with Spearman's $R$ value $>0.8$ were considered as significant here. This procedure will help in identifying the parameters that can potentially serve as surrogates for the other parameters (could be helpful in reducing the number of parameters we did for characterization of stormwater).
The inter-parameter relationships obtained have been used in deciding the optimal scheme of treatment. Treatment of the stormwater for one parameter is believed to result in coincidental removal of other closely related parameters.

Rainfall data analysis and assessment of stormwater quality

Rainfall events of less than $2.5 \mathrm{~mm}$ size (in some cases even up to $5 \mathrm{~mm}$ size) yielded too little stormwater to sample. No two storm events having antecedent dry days less than four were sampled as per guidelines specified in Caltrans Stormwater Monitoring Protocol Guidance Manual (Caltrans 2000, 2002).

Rainfall data obtained from Indian Meteorological Department for the period of 6 years (2006-2011) were analyzed documenting the antecedent dry period and corresponding average rainfall that occurred over these years. The purpose behind such an assessment was to predict stormwater quality over the set of various conditions (best, average and worst) of storm events. Regression models were used in predicting the stormwater quality in terms of 
Table 1 Mean values of the parameters analyzed along with their permissible limits as per Indian surface water quality guidelines (Arora and Reddy 2013)

\begin{tabular}{|c|c|c|c|c|c|c|c|}
\hline Parameter & Units & Model Town & Civil Lines & Manjit Nagar & Preet Nagar & Bus Stand & Permissible limits (EP rules 1986) \\
\hline $\mathrm{BOD}^{\#}$ & $\mathrm{mg} / \mathrm{L}$ & 19.1 & 12.1 & 18.7 & 12.7 & 33.5 & 30.0 \\
\hline $\mathrm{COD}^{\#}$ & $\mathrm{mg} / \mathrm{L}$ & 214.3 & 67.3 & 122.3 & 111.6 & 324.7 & 250.0 \\
\hline $\mathrm{TSS}^{\#}$ & $\mathrm{mg} / \mathrm{L}$ & 114.5 & 27.8 & 96.8 & 61.9 & 268.5 & 100.0 \\
\hline TDS & $\mathrm{mg} / \mathrm{L}$ & 32.7 & 21.9 & 43.5 & 23.1 & 40.6 & $2,100.0$ \\
\hline Oil and Grease ${ }^{\#}$ & $\mathrm{mg} / \mathrm{L}$ & 143.4 & 5.8 & 29.4 & 14.4 & 106.0 & 10.0 \\
\hline TKN & $\mathrm{mg} / \mathrm{L}$ & 9.7 & 9.2 & 10.4 & 7.6 & 10.9 & 100.0 \\
\hline $\mathrm{TP}$ & $\mathrm{mg} / \mathrm{L}$ & 0.56 & 0.67 & 0.71 & 0.73 & 0.80 & 5.0 \\
\hline Total coliform ${ }^{\#}$ & $\begin{array}{l}\text { MPN/ } \\
100 \mathrm{~mL}\end{array}$ & $2.07 \mathrm{E}+06$ & $4.44 \mathrm{E}+06$ & $5.57 \mathrm{E}+05$ & $2.10 \mathrm{E}+05$ & $1.59 \mathrm{E}+06$ & $*$ \\
\hline Fecal coliform ${ }^{\#}$ & $\begin{array}{l}\text { MPN/ } \\
100 \mathrm{~mL}\end{array}$ & $9.33 \mathrm{E}+05$ & $2.11 \mathrm{E}+06$ & $1.90 \mathrm{E}+05$ & $5.79 \mathrm{E}+04$ & $4.62 \mathrm{E}+05$ & $*$ \\
\hline $\mathrm{Zn}$ & $\mathrm{mg} / \mathrm{L}$ & 0.74 & 0.28 & 0.88 & 0.44 & 2.02 & 5.0 \\
\hline $\mathrm{Cd}$ & $\mathrm{mg} / \mathrm{L}$ & BDL & BDL & BDL & BDL & BDL & 2.0 \\
\hline $\mathrm{Ni}$ & $\mathrm{mg} / \mathrm{L}$ & BDL & BDL & BDL & BDL & BDL & 3.0 \\
\hline $\mathrm{Pb}^{\#}$ & $\mathrm{mg} / \mathrm{L}$ & BDL & BDL & BDL & BDL & 0.28 & 0.1 \\
\hline $\mathrm{Fe}^{\#}$ & $\mathrm{mg} / \mathrm{L}$ & 42.4 & 10.0 & 36.9 & 17.5 & 92.6 & 3.0 \\
\hline $\mathrm{Cu}$ & $\mathrm{mg} / \mathrm{L}$ & 0.21 & 0.06 & 0.08 & 0.09 & 0.90 & 3.0 \\
\hline
\end{tabular}

BDL-below detection limits $(0.01,0.3$ and $0.05 \mathrm{mg} / \mathrm{L}$ for $\mathrm{Cd}, \mathrm{Ni}$ and $\mathrm{Pb}$, respectively)

* At present there is no standard permissible limit set by CPCB for coliform count

\# Parameters identified as major pollutants as per Indian surface water quality (CPCB) guidelines

potentially important parameters by making use of the regression equations developed. The results obtained will provide fair idea for range of the pollution parameters to be treated. These findings could be useful in deciding the units of treatment scheme. The sizing of these units will be based on the volumes of stormwater to be treated, and the concept of water quality treatment volume (WQv) has been employed for assessing the same and thus aiding in reduced requirement for capture and treatment.

\section{Results and discussion}

Characteristics of stormwater

Mean values of results obtained by analyzing the stormwater samples collected from the five sub-watersheds are listed in Table 1 . The water quality parameters, whose concentrations exceeded the effluent standards for safe disposal into inland surface waters, specified in Schedule VI of EP rules, 1986, have been identified as the major pollutants in urban stormwater and are indicated in Table 1.

Often in highly urbanized catchments, road surfaces can typically constitute up to $22 \%$ of total catchment area and contribute up to $26 \%$ of total runoff volumes with commensurate contributions to total 'heavy' metal (e.g., $\mathrm{Cu}$,
$\mathrm{Pb}, \mathrm{Zn}$ ) loads of 19-40 \% (Davis and Birch 2010). Yusop et al. (2005) and Huang et al. (2007) had similar observation for TSS and COD during their research in a tropical urban catchment with a land-use composition of about $27 \%$ agriculture, $37 \%$ residential and commercial and $28 \%$ lawn/parks/bushes. Current study observed similar trends with regard to the pollutant concentrations and showed considerable variations among the events and with the sub-watershed type. Among the catchments studied, highest concentration of oil and grease was observed in Model Town. This can be attributed to the commercial characteristic of the sub-watershed (has an automobile workshop within the catchment boundary). COD, TSS and coliform have also been found as major pollutants in the stormwater. The maximum concentration of BOD, COD and TSS (33.5, 325 and $269 \mathrm{mg} / \mathrm{L}$, respectively) has been observed in the highly travelled and fully urbanized subwatershed of Bus Stand. Of the metals analyzed, only $\mathrm{Cu}$, $\mathrm{Fe}, \mathrm{Zn}$ and $\mathrm{Pb}$ were detected in the samples. Concentration of the metals, $\mathrm{Ni}$ and $\mathrm{Cd}$, was below detection limits $(0.30$ and $0.01 \mathrm{mg} / \mathrm{L}$, respectively). Maximum concentration of $\mathrm{Cu}, \mathrm{Fe}$ and $\mathrm{Zn}(0.90,93$ and $2.02 \mathrm{mg} / \mathrm{L}$, respectively) was observed in samples collected from the Bus Stand. The overall results indicate that the surface runoff of the Patiala city is badly polluted especially for TSS, COD and microbial count. 
Table 2 Correlation matrix (model town)

\begin{tabular}{|c|c|c|c|c|c|c|c|c|c|c|c|c|}
\hline & BOD & COD & TSS & TDS & $\begin{array}{l}\text { Oil and } \\
\text { grease }\end{array}$ & TKN & $\mathrm{TP}$ & $\begin{array}{l}\text { Total } \\
\text { coliform }\end{array}$ & $\begin{array}{l}\text { Fecal } \\
\text { coliform }\end{array}$ & $\mathrm{Zn}$ & $\mathrm{Fe}$ & $\mathrm{Cu}$ \\
\hline BOD & 1.000 & 0.061 & 0.271 & 0.250 & 0.334 & 0.832 & 0.157 & 0.621 & 0.634 & 0.756 & 0.807 & 0.736 \\
\hline COD & & 1.000 & 0.858 & 0.383 & 0.844 & -0.283 & -0.466 & 0.266 & 0.259 & 0.568 & 0.524 & 0.422 \\
\hline TSS & & & 1.000 & 0.250 & 0.972 & 0.089 & -0.466 & 0.319 & 0.316 & 0.824 & 0.762 & 0.642 \\
\hline TDS & & & & 1.000 & 0.433 & 0.034 & 0.254 & 0.509 & 0.518 & 0.355 & 0.281 & 0.302 \\
\hline $\begin{array}{l}\text { Oil and } \\
\text { grease }\end{array}$ & & & & & 1.000 & 0.171 & -0.274 & 0.494 & 0.493 & 0.851 & 0.760 & 0.617 \\
\hline TKN & & & & & & 1.000 & 0.465 & 0.638 & 0.648 & 0.571 & 0.553 & 0.419 \\
\hline Total-P & & & & & & & 1.000 & 0.627 & 0.627 & -0.199 & -0.303 & -0.465 \\
\hline $\begin{array}{l}\text { Total } \\
\text { coliform }\end{array}$ & & & & & & & & 1.000 & 1.000 & 0.566 & 0.460 & 0.200 \\
\hline $\begin{array}{l}\text { Fecal } \\
\text { coliform }\end{array}$ & & & & & & & & & 1.000 & 0.574 & 0.470 & 0.215 \\
\hline $\mathrm{Zn}$ & & & & & & & & & & 1.000 & 0.977 & 0.872 \\
\hline $\mathrm{Fe}$ & & & & & & & & & & & 1.000 & 0.938 \\
\hline $\mathrm{Cu}$ & & & & & & & & & & & & 1.000 \\
\hline
\end{tabular}

Table 3 Correlation matrix (Civil Lines)

\begin{tabular}{|c|c|c|c|c|c|c|c|c|c|c|c|c|}
\hline & BOD & COD & TSS & TDS & $\begin{array}{l}\text { Oil and } \\
\text { grease }\end{array}$ & TKN & $\mathrm{TP}$ & $\begin{array}{l}\text { Total } \\
\text { coliform }\end{array}$ & $\begin{array}{l}\text { Fecal } \\
\text { coliform }\end{array}$ & $\mathrm{Zn}$ & $\mathrm{Fe}$ & $\mathrm{Cu}$ \\
\hline BOD & 1.000 & 0.489 & 0.569 & -0.328 & 0.618 & -0.403 & 0.700 & 0.853 & 0.868 & 0.421 & 0.576 & 0.159 \\
\hline COD & & 1.000 & 0.963 & -0.259 & 0.883 & -0.068 & -0.127 & 0.014 & 0.039 & 0.441 & 0.258 & 0.230 \\
\hline TSS & & & 1.000 & -0.428 & 0.974 & -0.150 & -0.096 & 0.128 & 0.140 & 0.648 & 0.448 & 0.389 \\
\hline TDS & & & & 1.000 & -0.588 & 0.827 & -0.168 & -0.196 & -0.175 & -0.735 & -0.433 & -0.211 \\
\hline $\begin{array}{l}\text { Oil and } \\
\text { grease }\end{array}$ & & & & & 1.000 & -0.276 & -0.037 & 0.212 & 0.216 & 0.759 & 0.534 & 0.422 \\
\hline TKN & & & & & & 1.000 & -0.580 & -0.389 & -0.386 & -0.376 & -0.258 & 0.119 \\
\hline Total-P & & & & & & & 1.000 & 0.883 & 0.894 & 0.021 & 0.354 & -0.113 \\
\hline $\begin{array}{l}\text { Total } \\
\text { coliform }\end{array}$ & & & & & & & & 1.000 & 0.998 & 0.320 & 0.658 & 0.238 \\
\hline $\begin{array}{l}\text { Fecal } \\
\text { coliform }\end{array}$ & & & & & & & & & 1.000 & 0.287 & 0.627 & 0.200 \\
\hline $\mathrm{Zn}$ & & & & & & & & & & 1.000 & 0.856 & 0.793 \\
\hline $\mathrm{Fe}$ & & & & & & & & & & & 1.000 & 0.863 \\
\hline $\mathrm{Cu}$ & & & & & & & & & & & & 1.000 \\
\hline
\end{tabular}

Inter-parameter relationship studies

Spearman's correlation analysis was undertaken for the identification of correlations between selected variables. The conclusions derived are given below.

Sub-watershed-1: Model town (commercial), Table 2.

- COD, TSS, oil and grease and the metals $\mathrm{Cu}, \mathrm{Fe}$ and $\mathrm{Zn}$ are very much correlated with each other. It can be inferred that most COD and oil and grease constituents are particle bound and the metals are preferably inorganic particles. This is evident from the correlation matrix obtained in Table 2, clearly indicating very strong correlation between COD-TSS $(r=0.858)$, TSS-Zn $\quad(r=0.824)$ and TSS-oil and grease $(r=0.972)$.

- All the heavy metals are very strongly correlated with each other and show a strong correlation with TSS, confirming that they are mostly particle bound and also it can be postulated that removal of any one of these contaminants can coincidently result in the removal of others.

- TDS, BOD, TKN, fecal and total coliform form other correlated group.

Sub-watershed-2: Civil Lines (residential), Table 3. 
Table 4 Correlation matrix (Manjit Nagar)

\begin{tabular}{|c|c|c|c|c|c|c|c|c|c|c|c|c|}
\hline & BOD & COD & TSS & TDS & $\begin{array}{l}\text { Oil and } \\
\text { grease }\end{array}$ & TKN & Total-P & $\begin{array}{l}\text { Total } \\
\text { coliform }\end{array}$ & $\begin{array}{l}\text { Fecal } \\
\text { coliform }\end{array}$ & $\mathrm{Zn}$ & $\mathrm{Fe}$ & $\mathrm{Cu}$ \\
\hline BOD & 1.000 & -0.519 & 0.617 & 0.534 & 0.574 & 0.702 & -0.706 & -0.003 & 0.193 & -0.703 & 0.489 & 0.673 \\
\hline COD & & 1.000 & 0.014 & 0.030 & -0.086 & -0.084 & 0.036 & 0.648 & 0.415 & 0.208 & 0.306 & -0.083 \\
\hline TSS & & & 1.000 & 0.978 & 0.981 & 0.669 & -0.748 & 0.454 & 0.236 & -0.725 & 0.833 & 0.887 \\
\hline TDS & & & & 1.000 & 0.963 & 0.582 & -0.641 & 0.475 & 0.230 & -0.658 & 0.739 & 0.777 \\
\hline $\begin{array}{l}\text { Oil and } \\
\text { grease }\end{array}$ & & & & & 1.000 & 0.655 & -0.669 & 0.398 & 0.161 & -0.745 & 0.757 & 0.886 \\
\hline TKN & & & & & & 1.000 & -0.433 & 0.604 & 0.695 & -0.976 & 0.524 & 0.727 \\
\hline Total-P & & & & & & & 1.000 & -0.027 & 0.070 & 0.406 & -0.904 & -0.839 \\
\hline $\begin{array}{l}\text { Total } \\
\text { coliform }\end{array}$ & & & & & & & & 1.000 & 0.875 & -0.540 & 0.385 & 0.285 \\
\hline $\begin{array}{l}\text { Fecal } \\
\text { coliform }\end{array}$ & & & & & & & & & 1.000 & -0.589 & 0.162 & 0.134 \\
\hline $\mathrm{Zn}$ & & & & & & & & & & 1.000 & -0.484 & -0.753 \\
\hline $\mathrm{Fe}$ & & & & & & & & & & & 1.000 & 0.879 \\
\hline $\mathrm{Cu}$ & & & & & & & & & & & & 1.000 \\
\hline
\end{tabular}

Table 5 Correlation matrix (Preet Nagar)

\begin{tabular}{|c|c|c|c|c|c|c|c|c|c|c|c|c|}
\hline & BOD & COD & TSS & TDS & $\begin{array}{l}\text { Oil and } \\
\text { grease }\end{array}$ & TKN & Total-P & $\begin{array}{l}\text { Total } \\
\text { coliform }\end{array}$ & $\begin{array}{l}\text { Fecal } \\
\text { coliform }\end{array}$ & $\mathrm{Zn}$ & $\mathrm{Fe}$ & $\mathrm{Cu}$ \\
\hline BOD & 1.000 & -0.033 & 0.868 & 0.696 & 0.838 & -0.684 & -0.542 & -0.810 & -0.811 & 0.136 & 0.115 & 0.136 \\
\hline COD & & 1.000 & 0.032 & -0.360 & -0.099 & -0.046 & -0.099 & -0.164 & -0.161 & 0.747 & 0.537 & 0.229 \\
\hline TSS & & & 1.000 & 0.549 & 0.990 & -0.420 & -0.224 & -0.693 & -0.671 & 0.054 & 0.223 & 0.000 \\
\hline TDS & & & & 1.000 & 0.566 & -0.083 & 0.037 & -0.850 & -0.852 & 0.237 & 0.396 & 0.616 \\
\hline $\begin{array}{l}\text { Oil and } \\
\text { grease }\end{array}$ & & & & & 1.000 & -0.376 & -0.171 & -0.637 & -0.615 & -0.064 & 0.152 & -0.053 \\
\hline TKN & & & & & & 1.000 & 0.977 & 0.236 & 0.255 & 0.155 & 0.462 & 0.377 \\
\hline Total-P & & & & & & & 1.000 & 0.124 & 0.149 & 0.118 & 0.500 & 0.366 \\
\hline $\begin{array}{l}\text { Total } \\
\text { coliform }\end{array}$ & & & & & & & & 1.000 & 0.999 & -0.598 & -0.637 & -0.677 \\
\hline $\begin{array}{l}\text { Fecal } \\
\text { coliform }\end{array}$ & & & & & & & & & 1.000 & -0.603 & -0.624 & -0.684 \\
\hline $\mathrm{Zn}$ & & & & & & & & & & 1.000 & 0.873 & 0.813 \\
\hline $\mathrm{Fe}$ & & & & & & & & & & & 1.000 & 0.845 \\
\hline $\mathrm{Cu}$ & & & & & & & & & & & & 1.000 \\
\hline
\end{tabular}

- Total-P and TKN are not correlated with each other and with TSS as indicated in Table 3 . However, TKN is weakly correlated with TDS, suggesting that most of the nutrients are in dissolved form.

- COD, oil and grease and heavy metals $\mathrm{Cu}$ are strongly correlated with each other and with TSS COD-TSS $(r=0.963)$, TSS-oil and grease $(r=0.974)$.

- Total coliform and fecal coliform show strong correlation ( $r=0.998$ ) for this residential sub-watershed, suggesting fecal matter to be the source of microbial contamination.
Sub-watershed-3: Manjit Nagar (rural acreage residential), Table 4.

- TKN is weakly correlated with TSS ( $r=0.669)$, suggesting most of the nitrogen to be in dissolved form.

- TSS, BOD, oil and grease and heavy metals $\mathrm{Cu}$ and Fe are correlated with each other. Strong correlation is indicated in Table 4: TSS-oil and grease $(r-0.981)$, TSS-Fe $(r=0.833)$, TSS-Cu $(r-0.887)$

- Total coliform and fecal coliform show strong correlation for this rural acreage sub-watershed $(r=0.875)$, 
Table 6 Correlation matrix (Bus Stand)

\begin{tabular}{|c|c|c|c|c|c|c|c|c|c|c|c|c|}
\hline & BOD & COD & TSS & TDS & $\begin{array}{l}\text { Oil and } \\
\text { grease }\end{array}$ & TKN & Total-P & $\begin{array}{l}\text { Total } \\
\text { coliform }\end{array}$ & $\begin{array}{l}\text { Fecal } \\
\text { coliform }\end{array}$ & $\mathrm{Zn}$ & $\mathrm{Fe}$ & $\mathrm{Cu}$ \\
\hline BOD & 1.000 & 0.523 & 0.576 & 0.658 & 0.169 & 0.097 & 0.035 & 0.625 & 0.582 & -0.004 & -0.035 & 0.042 \\
\hline COD & & 1.000 & 0.983 & 0.955 & 0.701 & 0.638 & -0.643 & 0.746 & 0.570 & 0.392 & 0.538 & 0.301 \\
\hline TSS & & & 1.000 & 0.921 & 0.650 & 0.562 & -0.577 & 0.757 & 0.546 & 0.336 & 0.466 & 0.264 \\
\hline TDS & & & & 1.000 & 0.557 & 0.512 & -0.644 & 0.767 & 0.560 & 0.248 & 0.398 & 0.161 \\
\hline $\begin{array}{l}\text { Oil and } \\
\text { grease }\end{array}$ & & & & & 1.000 & 0.987 & -0.165 & 0.452 & 0.780 & 0.878 & 0.874 & 0.829 \\
\hline TKN & & & & & & 1.000 & -0.162 & 0.360 & 0.747 & 0.911 & 0.909 & 0.855 \\
\hline Total-P & & & & & & & 1.000 & -0.328 & 0.159 & 0.080 & -0.206 & 0.239 \\
\hline $\begin{array}{l}\text { Total } \\
\text { coliform }\end{array}$ & & & & & & & & 1.000 & 0.694 & -0.001 & 0.025 & -0.041 \\
\hline $\begin{array}{l}\text { Fecal } \\
\text { coliform }\end{array}$ & & & & & & & & & 1.000 & 0.585 & 0.471 & 0.602 \\
\hline $\mathrm{Zn}$ & & & & & & & & & & 1.000 & 0.956 & 0.985 \\
\hline $\mathrm{Fe}$ & & & & & & & & & & & 1.000 & 0.898 \\
\hline $\mathrm{Cu}$ & & & & & & & & & & & & 1.000 \\
\hline
\end{tabular}

suggesting fecal matter to be the prime source of microbial contamination.

Sub-watershed-4: Preet Nagar (mixed urban), Table 5.

- Total-P and TKN are strongly correlated with each other $(r=0.977)$ but are not correlated with TSS as indicated in Table 5. Hence, most of the nutrients are in dissolved form.

- Biodegradable organic pollutants, TSS and oil and grease are strongly correlated with each other, BODTSS $(r=0.868)$, TSS-oil and grease $(r=0.990)$.

- Heavy metals $\mathrm{Fe}, \mathrm{Cu}$ and $\mathrm{Zn}$ exist primarily in dissolved form for this sub-watershed.

- Total coliform and fecal coliform show strong correlation $(r=0.999)$ for this residential sub-watershed suggesting fecal matter to be the source of microbial contamination.

Sub-watershed-5: Bus Stand (heavily travelled urban), Table 6.

- $\quad$ TKN, oil and grease and the heavy metals $\mathrm{Fe}, \mathrm{Cu}$ and $\mathrm{Zn}$ are strongly correlated with each other and exist primarily in dissolved form for this sub-watershed, $r$ value $>0.9$ have been observed as indicated in Table 6.

- BOD, COD and total coliform are particle bound and form strong correlation with TSS.

- Total coliform and fecal coliform show weak correlation $(r=0.694)$ for this urbanized sub-watershed suggesting other sources of microbial contamination than fecal matter.
The results obtained in effect mean that the mere provision of standard structural measures such as structural best management practices (BMPs) may not be necessarily effective in removing water quality pollutants. Any structural measures to be adopted should depend on targeted pollutants, and management strategies adopted should take into consideration the rainfall, runoff and physical characteristics of the area. The inter-parameter relationship assessment could help a great deal in selecting a scheme of treatment targeted toward the removal of certain selected parameters and not all the constituents as the removal of a certain parameter can coincidentally result in the removal of those associated with it.

Stormwater quality assessment through modeling

Stormwater is usually of better quality than untreated sewage or industrial discharge (Mitchell et al. 2002; Hatt et al. 2006) and as such has better public acceptance for utilization. All these factors make it a potentially valuable resource for water supply substitution after suitable treatment. In order to prioritize the implementation of stormwater treatment measures, urban waterway managers need to be able to predict and assess their performance, both individually and in various combinations. There is thus a strong demand for predictive models that can be applied across a range of locations and conditions, to predict the general characteristics of stormwater and performance of a range of stormwater treatment measures (Phillips and Thompson 2002). It is practically impossible to analyze each and every storm event, but one can predict the 
pollutant concentration using the regression models (Arora and Reddy 2014). This prediction can serve as an effective tool in deciding for the scheme of treatment for particular design storm with the known concentrations of pollutants that are expected to be taken care off.

Site and event parameters (antecedent dry period, cumulative seasonal rainfall, drainage area and annual average daily traffic) were found to have significant influences on pollutant load, as reported earlier (Graves et al. 2004; Kayhanian et al. 2007). Pollutant load from urban surface runoff depends largely on both buildup and washup processes. The buildup depends on the ADD, land use, wind speed and traffic. Wash off may be a function of rainfall intensity and other factors (Kim et al. 2005, 2006). Few researchers determined the effect of the antecedent dry period in their study of stormwater discharge (Saget et al. 1996; Lee et al. 2002). (Ball et al. 1998) tried to find a buildup model using regressions of ADD. It is believed that the rainfall intensity has a negative effect on the pollutant load accumulated and is responsible for the wash off or diluting of the pollutants. Keeping this in mind, modeling was done with the interest of predicting the concentrations of the pollution parameters, knowing the two variables of ADD and rainfall. Strength for the model fit was observed to be greatest for TSS and oil and grease for all the subwatersheds, suggesting that the two parameters can be interpreted knowing the two variables of ADD and rainfall.

Rainfall against antecedent dry days was analyzed for different set of conditions over the 6-year period. Multiple regression models were used for stormwater quality assessment under three set of conditions: firstly, worst conditions for stormwater quality [minimum rainfall $(13 \mathrm{~mm})$ and maximum dry period (98 days)]; secondly, average or moderate conditions [average rainfall $(56 \mathrm{~mm})$ and average length of dry period (30 days)]; lastly, best conditions for stormwater quality [maximum rainfall $(115 \mathrm{~mm})$ and minimum dry days (5 days)]. The values have been obtained using regression equation in cases where the $R^{2}$ value is greater than 2-sigma value in a normal distribution, i.e., $95 \%$. It is believed that this criterion will yield strong, moderate and weak relationships in terms on $R^{2}$ values and signify the importance and reliability of the obtained results through regression modeling. In cases where $R^{2}$ values are less than 1 sigma, i.e., $68.2 \%$, it is assumed that weak or no relation is observed and hence regression equations will provide misleading results. In such cases maximum, minimum and average values obtained by actual analysis of parameters were used. The assessment of water quality parameters will help in predicting the quality well before actually analyzing the parameters and thus aid in developing treatment schemes suitable for taking care of the stormwater quality even under worst set of conditions.
Table 7 Inter-parameter relationships established among different parameters

\begin{tabular}{|c|c|c|}
\hline $\begin{array}{l}\text { Sub- } \\
\text { watershed }\end{array}$ & $\begin{array}{l}\text { Inter-parameter } \\
\text { Relationships }\end{array}$ & Remarks \\
\hline $\begin{array}{l}\text { Model } \\
\text { Town }\end{array}$ & $\begin{array}{l}\text { 1. COD-TSS-oil } \\
\text { and grease } \\
\text { 2. TSS-Zn } \\
\text { 3. Oil and grease-- } \\
\mathrm{Zn} \\
\text { 4. } \mathrm{Zn}-\mathrm{e}-\mathrm{Cu}\end{array}$ & $\begin{array}{l}\text { It can be postulated that treatment } \\
\text { scheme designed for removal of } \\
\text { BOD, TSS and oil and grease will } \\
\text { eventually take care of the rest of } \\
\text { the significant parameter on } \\
\text { account of their association with } \\
\text { these } 3 \text { parameters }\end{array}$ \\
\hline $\begin{array}{l}\text { Civil } \\
\text { Lines }\end{array}$ & $\begin{array}{l}\text { 1. BOD-TC-FC } \\
\text { 2. COD-TSS-oil } \\
\text { and grease } \\
\text { 3. TDS-TKN } \\
\text { 4. TP-TC-FC } \\
\text { 5. } \mathrm{Zn}-\mathrm{Fe}-\mathrm{Cu}\end{array}$ & $\begin{array}{l}\text { Treatment scheme designed should } \\
\text { have provision for the removal of } \\
\text { organics, TSS, Fe and coliform. } \\
\text { Rest of the parameters is not in } \\
\text { significant proportions and will be } \\
\text { reduced coincidentally to lower } \\
\text { levels }\end{array}$ \\
\hline $\begin{array}{l}\text { Manjit } \\
\text { Nagar }\end{array}$ & $\begin{array}{l}\text { 1. TSS-TDS-oil } \\
\text { and grease } \\
\text { 2. Oil and grease- } \\
\mathrm{Fe}-\mathrm{Cu} \\
\text { 3. TC-FC }\end{array}$ & $\begin{array}{l}\text { Strong correlations among the } \\
\text { parameters suggest that removal } \\
\text { of any two will coincidentally } \\
\text { reduce the concentrations of the } \\
\text { others } \\
\text { Treatment unit should be designed } \\
\text { for the removal of TSS, oil and } \\
\text { grease and coliform }\end{array}$ \\
\hline $\begin{array}{l}\text { Preet } \\
\text { Nagar }\end{array}$ & $\begin{array}{l}\text { 1. BOD-TSS-oil } \\
\text { and grease } \\
\text { 2. TKN-TP } \\
\text { 3. TC-FC } \\
\text { 4. } \mathrm{Zn}-\mathrm{Fe}-\mathrm{Cu}\end{array}$ & $\begin{array}{l}\text { For Preet Nagar, sub-watershed } \\
\text { treatment system should be } \\
\text { designed for the removal of TSS, } \\
\text { coliform and heavy metals. Rest } \\
\text { of the parameters will get reduced } \\
\text { coincidentally in account with } \\
\text { their inter-parameter relationship } \\
\text { with the parameters addressed }\end{array}$ \\
\hline $\begin{array}{l}\text { Bus } \\
\text { Stand }\end{array}$ & $\begin{array}{l}\text { 1. COD-TSS- } \\
\text { TDS } \\
\text { 2. Oil and grease- } \\
\text { TKN-Zn-Fe- } \\
\mathrm{Cu}\end{array}$ & $\begin{array}{l}\text { Taking into account the significant } \\
\text { parameters along with the inter- } \\
\text { parameter relationships obtained, } \\
\text { the treatment scheme should be } \\
\text { designed for BOD, TSS, oil and } \\
\text { grease, Fe and coliform removal }\end{array}$ \\
\hline
\end{tabular}

Scheme of treatment and commenting its suitability

Scheme of treatment has been conceptualized keeping in mind the target pollutants decided by estimating the failing frequency of a particular parameter in a sub-watershed. Microbial count and $\mathrm{Fe}$ have failed in all the stormwater samples collected from respective sub-watersheds and have been listed as top priority pollutants followed by oil and grease, TSS and COD.

Inter-parameter relationships established through correlations have been listed in Table 7. These relationships appreciably guided in making selections for the minimum number of treatment units required for attaining stormwater of desired quality.

Based on the correlations observed among different parameters, it is postulated that the removal of TSS, oil and grease, BOD, Fe and coliform will effectively take care of 


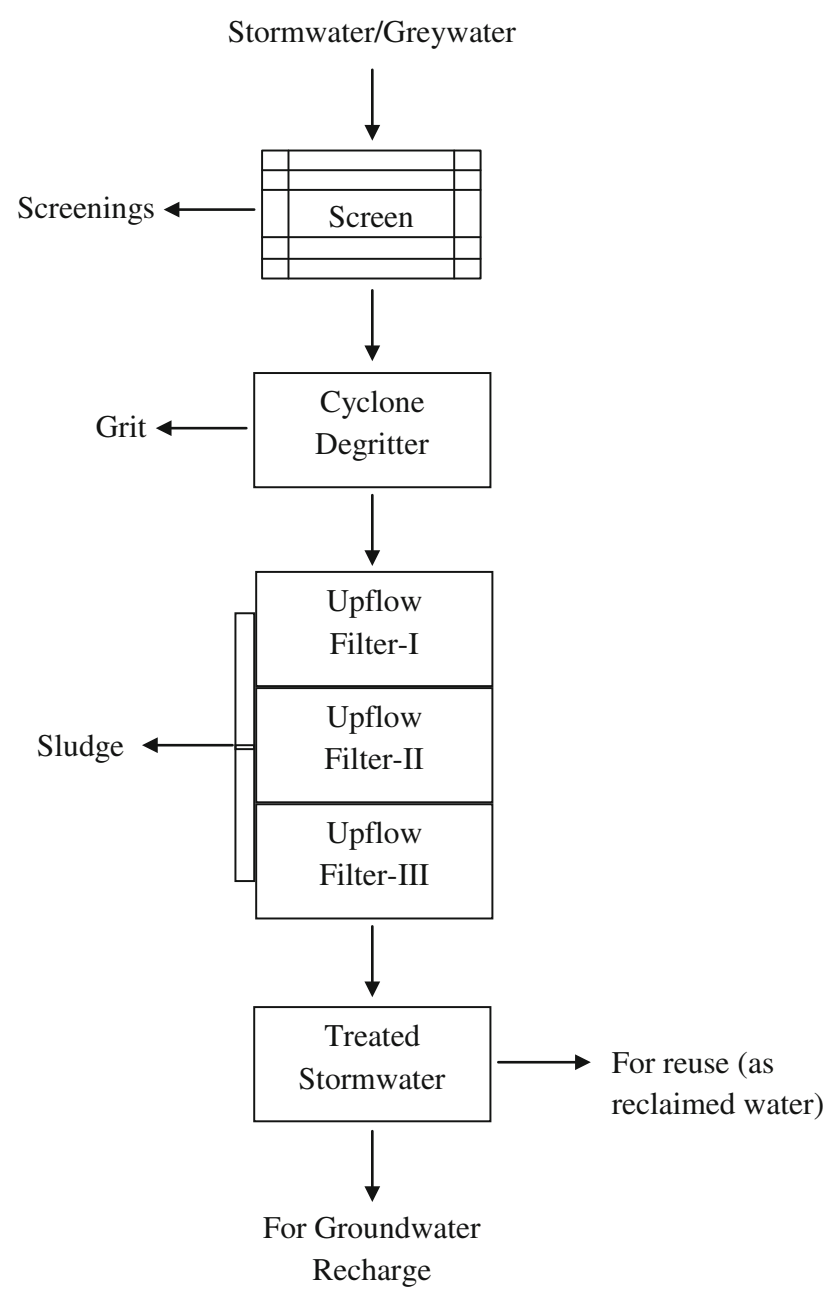

Fig. 2 Layout of the treatment scheme

the rest of the parameters. So the scheme of treatment that will be most suitable for all the sub-watersheds should have the following units:

- Screen: for the removal of the litter, leaves and bigger size particles that will come along with stormwater.

- Cyclone de-gritter: for grit removal and removal of heavier particles or suspended solids to avoid clogging of the filters

- Clarification/filtration unit: clarification for removing oil and grease.

- Multi-grade up-flow filter-I: consisting of layers of greater size pebbles followed by coarse sand for removal of sediment and biodegradable organics. This unit will act as a biological treatment unit and will result in BOD and COD reduction from the stormwater.

- Multi-grade up-flow filter-II: consisting of smaller size sand particles decreasing in size. This filter in addition to biological processes is supposed to take care of the coliform count.

- Final filtration unit: Designed for removal of the additional pollutants remaining in the treated stormwater.

It is believed that such an up-flow multi-grade multistage filter will be able to treat the stormwater to the level safe for groundwater recharge and will satisfy the quality requirements for groundwater recharging. Figure 2 provides the layout of the treatment scheme conceptualized. During the dry periods, gray water from the residential compartments will be allowed to pass through the treatment unit. This will, in addition to conserving water, keep the treatment system functional during dry days and enhance the groundwater recharge potential.

\section{Conclusion}

Comparison of the results obtained by analyzing the collected stormwater samples with the prescribed effluent standards for discharge into inland surface waters indicated that BOD, COD, TSS, oil and grease, total coliform count, fecal coliform count, $\mathrm{Pb}$ and $\mathrm{Fe}$ are the important pollution parameters and should be focused on during the stormwater treatment.

While TSS, COD and oil and grease are the critical pollution parameters for all the five sub-watersheds, major pollutants from surface runoff is generated from commercial catchment of model town with mean concentration of 114.5, 214 and $143 \mathrm{mg} / \mathrm{L}$ and urbanized catchment of Bus Stand with mean concentration of 268.5, 325 and $106 \mathrm{mg} /$ L. Of all the sub-watersheds, the water quality of the residential catchment of Civil Lines was better as compared to the others, barring the microbial count which was observed to be the highest for this sub-watershed.

This paper identifies appreciable insights into nonurban, urbanizing, mixed urban and urban catchments. The common management technique of dealing with suspended materials as a primary treatment for urban stormwater quality is shown to be less effective. TP, TKN, TDS and oil and grease may not be taken care of as desired. It is important that predictive models be developed to take these characteristics into consideration.

Further, the study signified the need to focus toward removal of targeted pollutants while taking into account the catchment characteristics, ADD and rainfall intensity along with the inter-parameter relationship and proposed appropriate and justified scheme of treatment which is believed to be suitable for treating the stormwaters of the city. 
Acknowledgments The authors would like to thank Thapar University, Patiala, for providing the laboratory facilities to undertake the task of testing and analysis.

\section{References}

APHA (2005) Standard methods for the examination of water and wastewater, 21st edn. American Public Health Association, Washington

Arora AS, Reddy AS (2013) Multivariate analysis for assessing the quality of stormwater from different urban surfaces of the Patiala city, Punjab (India). Urban Water J 10(6):422-433

Arora AS, Reddy AS (2014) Development of multiple linear regression models for predicting the stormwater quality of urban sub-watersheds. Bull Environ Contam Toxicol. doi:10.1007/ s00128-013-1160-y

Ball JE, Jenks R, Aubourg D (1998) An assessment of the availability of pollutant constituents on road surfaces. Sci Total Environ 209:243-254

Birch GF, Fazeli MS, Matthai C (2005) Efficiency of an infiltration basin in removing contaminants from urban stormwater. Environ Monit Assess 101:23-38

Birch GF, Matthai C, Fazeli MS (2006) Efficiency of a retention/ detention basin to remove contaminants from urban stormwater. Urban Water J 3(2):69-77

Caltrans (2000) Guidance Manual: Stormwater Monitoring Protocols. Report no. CTSW-RT-00-005. California Department of Transportation, Sacramento

Caltrans (2002) Monitoring and Water Quality Research Program: 2002-2003 Data Reporting Protocols, Report no CTSW-RT-02067. California Department of Transportation, Sacramento

Chang M, McBroom MW, Beasley RS (2004) Roofing as a source of non-point water pollution. J Environ Manag 73:307-315

Chebbo G, Gromaire MC (2004) The experimental urban catchment "Le Marais" in Paris: what lessons can be learn from it? J Hydrol 299:312-323

Choe JS, Bang KW, Lee LH (2002) Characterization of surface runoff in urban areas. Water Sci Technol 45(9):249-254

Davis B, Birch G (2010) Comparison of heavy metal loads in stormwater runoff from major and minor urban roads using pollutant yield rating curves. Environ Pollut 158(8):2541-2545

Davis AP, Shokouhian M, Sharma H, Minami C (2001) Laboratory study of biological retention for urban stormwater management. Water Environ Res 73:5-14

Deletic A (1998) The first flush load of urban surface runoff. Water Res 32(8):2462-2470
Gnecco I, Berretta C, Lanza LG (2005) Storm water pollution in the urban environment of Genoa, Italy. Atmospheric Res 77:60-73

Goonetilleke A, Thomas E, Ginn S (2005) Understanding the role of land use in urban stormwater quality management. J Environ Manag 74:31-42

Graves G, Wan Y, Fike L (2004) Water quality characteristics of stormwater from major land uses in South Florida. J Am Water Resour Assoc 40:1405-1419

Hatt BE, Deltic A, Fletcher TD (2006) Integrated treatment and recycling of stormwater: a review of Australian practice. J Environ Manag 79:102-113

Hossain I, Imteaz MA, Hossain MI (2011) Application of build-up and wash-off models for an East-Australian catchment. Int $\mathrm{J}$ Civil Environ Eng 3(3):156-161

Huang JL, Du PF, Ao CT, Lei MH, Zhao DQ, Ho MH, Wang ZS (2007) Characterization of surface runoff from a subtropics urban catchment. J Environ Sci 19(2):148-152

Kayhanian M, Suverkropp C, Ruby A, Tsay K (2007) Characterization and prediction of highway runoff constituent event mean concentration. J Environ Manag 85:279-295

Kim LH, Kayhanian M, Lau SL, Stenstrom MK (2005) A new modeling approach in estimating first flush metal mass loading. Water Sci Technol 51(3-4):159-167

Kim LH, Zoh KD, Jeong S, Kayhanian M, Stenstrom MK (2006) Estimating pollutant mass accumulation on highways during dry periods. J Environ Eng 132(9):985-993

Lee JH, Bang KW, Ketchum LH, Choe JS, Yu MJ (2002) First flush analysis of urban storm runoff. Sci Total Environ 193:163-175

Mitchell VG, Mein RG, McMahon TA (2002) Utilising stormwater and wastewater resources in urban areas. Aust J Water Resour $6(1): 31-43$

Phillips BC, Thompson G (2002) Virtual stormwater management planning in the 21st century. Ninth international conference on urban drainage, Portland, Oregon

Saget A, Chebbo G, Bertrand-Krajewski JL (1996) The first flush in sewer systems. Water Sci Technol 33(9):101-108

Taebi A, Droste RL (2004) Pollution loads in urban runoff and sanitary wastewater. Sci Total Environ 327:175-184

The Environment (Protection) Rules (1986) Schedule-VI, General standards for discharge of environmental pollutants part A: effluents. Pollution control law series: PCLS/02/2010, Central Pollution Control Board, New Delhi

Yaziz MI, Gunting H, Sapari N (1989) Variations in rainwater quality from roof catchments. Water Res 23(6):761-765

Yusop Z, Tan LW, Ujang Z (2005) Runoff quality and pollution loadings from a tropic urban catchment. Water Sci Technol 52(9):125-132 